\title{
Nomenclatural Novelties in Anthurium sect. Urospadix subsect. Obscureviridia from the Brazilian Atlantic Forest
}

\author{
Rodrigo Theófilo Valadares, ${ }^{*}$ Luana S. B. Calazans, and \\ Cassia Mônica Sakuragui \\ Universidade Federal do Rio de Janeiro/Museu Nacional, Programa de Pós-Graduação em \\ Ciências Biológicas (Botânica), Quinta da Boa Vista, s/n, São Cristóvão, CEP 20940-040, \\ Rio de Janeiro, RJ, Brazil. \\ *Author for correspondence: rodrigotheofilo@yahoo.com.br
}

Aвstract. This paper presents and discusses nomenclatural novelties concerning names of Atlantic Forest species of Anthurium Schott sect. Urospadix Engl. in subsection Obscureviridia Engl. Nine lectotypifications, four neotypifications, one correction of authorship, and one clarification of a type are presented and discussed, and four designations are noted not to have been validly published.

Key words: Anthurium, Araceae, Engler, lectotypification, neotypification, Regel, Schott.

Anthurium Schott is the most diverse genus of Araceae and stands out for presenting a taxonomy in which vegetative characters have been largely used as more informative in comparison to inflorescence characters. However, this fact makes distinction among species challenging (Coelho et al., 2009). The genus presents a wide Neotropical distribution, which, along with its distinctive morphological features, motivated Schott (1829) to separate the group from Pothos L., where the firstrecognized species were previously placed.

The taxonomic history of Anthurium is marked by an infrageneric division in "grex" groups by Schott (1860) and later into sections and subsections by Engler (1878, 1898). The information gathered in the 19th century was consolidated in the revision Das Pflanzenreich (Engler, 1905), which is considered, to date, a fundamental work of reference for taxonomic studies (e.g., Croat, 1991; Coelho et al., 2009). In this work, Engler (1905) recognized section Urospadix Engl. as the most representative in Brazil and divided it into six morphologically defined subsections.

Since the mid-20th century, various nomenclatural studies dealing with section Urospadix were performed by several authors (e.g., Croat, 1976, 1991; Mayo, 1982; Coelho \& Mayo, 2007), although a representative group of species belonging to subsection Obscureviridia Engl., found in eastern Brazil, still needs revision. This subsection is represented by 23 species in the Atlantic Forest (Valadares \& Sakuragui, 2014), and it is characterized by chartaceous to coriaceous concolored blades, with barely visible primary lateral veins (Engler, 1898; Coelho et al., 2009; Valadares \& Sakuragui, 2014). The latest in-depth study of species from this geographic region, published by Coelho and Mayo (2007), resulted in important nomenclatural and taxonomic changes in the genus, but it was restricted to subsection Flavescentiviridia Engl.

As a contribution to the ongoing taxonomic review of the species belonging to subsection Obscureviridia in the Atlantic Forest, we present here a nomenclatural study with new adjustments in accordance with the International Code of Nomenclature for algae, fungi, and plants (ICN) (Turland et al., 2018). We deal only with nomenclatural questions here, without addressing the current taxonomic status of the species names, which will be properly addressed in the taxonomic revision forthcoming.

\section{Materials AND Methods}

Searches for historical references to the names associated with Anthurium subsect. Obscureviridia were exhaustively conducted in the databases of the Biodiversity Heritage Library (<https://www.biodiversitylibrary. org $>$ ), Botanicus Digital Library (<http://www.botanicus. org $>$ ), and Internet Archive (<http://www.archive.org $>$ ).

After consulting the protologues of the published names, we searched for the collected materials associated with the identified collectors according to information found in the literature (Stafleu \& Cowan, 1976-1988), including images and exsiccatae in several herbaria, as well as other materials that could be unambiguously associated with the original description. Curators' personal communications were also decisive in checking the existence of the material in the herbaria. The herbaria consulted were: ALCB, B, BHCB, BM, BR, C, CEPEC, CTES, CVRD, E, F, G, H, HBR, HPL, HUEFS, IPA, K, L, LE, LG, M, MBM, MBML, MO, NY, OXF, P, R, RB, S, SEL, SP, SPF, U, UB, US, WAG, VIES, and W (acronyms according to Thiers, 2019 
[continuously updated]). Names of species included in subsection Obscureviridia without nomenclatural problems are not presented in this paper.

For nomenclatural interpretation of each name, we followed the ICN (Turland et al., 2018) and the recommendations of Turland (2013). The decision-making process applied to each name is indicated along with relevant articles of the ICN as appropriate.

\section{Nomenclatural Treatment}

Anthurium Schott subsect. Obscureviridia Engl., Bot. Jahrb. 25: 393. 1898. TYPE: Anthurium coriaceum G. Don. (lectotype, designated here).

Notes. No type was specified for the subsection, which was described with several associated species. We designate Anthurium coriaceum as the lectotype as it best corresponds to the characteristics in the description of Anthurium subsect. Obscureviridia.

1. Anthurium binotii Linden ex Regel, Gartenflora 21: 131, t. 723. 1872. TYPE: [Icon in] Regel, Gartenflora 21: t. 723.1872 (lectotype, designated here, t. 723 in Regel [1872]).

Notes. Anthurium binotii was described by Eduard von Regel (1872) as a new species, with its name ascribed to Jean Jules Linden, an ascription that has generally been followed by later authors. Since there is no indication that Linden provided a valid description, the name must be cited as A. binotii Linden ex Regel.

In searches for Regel exsiccatae in the European herbaria, we found a specimen in St. Petersburg (LE) with the following annotation: "Anthurium binoti Linden. teste Regel." Although the specimen has been identified by Regel and would be a reasonable candidate to be the type, comparative analysis of the protologue and associated illustration does not provide clear evidence that the specimen certainly belongs to the original material. Therefore, we opted for lectotypifying the name under the only material unambiguously attached to the protologue, the illustration. Kew Herbarium has some specimens of Anthurium binotii distributed by Glaziou (as living plants, or specimens, or both), which are frequently treated as types. Perhaps the plant at Linden's garden, in Belgium, was sent there by Glaziou, but there is neither evidence for it nor any mention of Glaziou in the protologue. Thus, these specimens are not relevant to the typification of $A$. binotii.

2. Anthurium coriaceum G. Don, Hort. Brit. [Sweet] 3: 633. 1839. Pothos coriaceus Graham, Edinburgh Philos. J. 353. 1826, nom. illeg. TYPE: Rio de Janeiro. (Cultivated in the Royal Botanic Gardens, Kew), J. Harris s.n. (lectotype, designated here, K000434179!; isolectotype, K000434178!).
Notes. Pothos coriaceus was described by Captain James Graham (1826) from a specimen cultivated in the Royal Botanic Gardens, Kew, sent by Joaquim Harris. The name is a later homonym of $P$. coriaceus, described by Richard Anthony Salisbury (1796) and is thus an illegitimate name. George Don (Sweet \& Don, 1839) later published an intended new combination, under Anthurium, in the third edition of Sweet's catalog of cultivated plants of Great Britain. The name must be credited to him alone.

We found two specimens associated with the name in European herbaria: the exsiccatae at K (K000434178 and K000434179) with the annotation "Rio Mrs. Graham." These exsiccatae are almost certainly from the material cultivated by Captain Graham, as is documented by Lauener and Paul (1985), although Harris is not mentioned on the label. We have chosen as lectotype the sheet that is morphologically more complete, with an entire leaf and inflorescence.

3. Anthurium gaudichaudianum Kunth, Enum. Pl. 3: 74. 1841. TYPE: [Brazil. Santa Catarina: Florianópolis], Insula St. Catherinae Brasiliensium, C. Gaudichaud-Beaupré s.n. (lectotype, designated here, L 0041847!).

Notes. Anthurium gaudichaudianum was validly published by Karl Sigismund Kunth (1841) based on material collected by Gaudichaud from Santa Catarina State, Brazil. The material indicated was probably destroyed during World War II, but we found a specimen at $\mathrm{L}$ that is presumably a duplicate of the material seen by Kunth. Therefore, we designate it as the lectotype.

Heinrich Gustav Adolf Engler (1905) recognized three varieties under Anthurium gaudichaudianum: "Anthurium gaudichaudianum var. cuneifolium Engl.," A. gaudichaudianum var. libonianum (Linden \& Regel) Engl., and A. gaudichaudianum var. chamissonis (Schott) Engl. "Anthurium gaudichaudianum var. cuneifolium" was not validly published because the taxon to which it was applied included the type of a name that should have been adopted according to ICN (Art. 26.2). The taxon should bear the autonym $A$. gaudichaudianum var. gaudichaudianum were we to recognize varieties. The other two names are discussed below.

4. Anthurium gaudichaudianum var. chamissonis (Schott) Engl., Fl. Bras. (Martius) 3(2): 85. 1878. Basionym: Anthurium chamissonis Schott, Oesterr. Bot. Wochenbl. 7: 269. 1857. TYPE: [Brazil]. Brasilia, L. K. A. von Chamisso s.n. (holotype, $\mathrm{B} \dagger$, photo F!). Brazil. Santa Catarina: Ilha de Santa Catarina, Unidade de Conservação Ambiental Desterro (UCAD), E. G. Gonçalves \& S. Vieira 
304 (neotype, designated here, UB 544!; isoneotype, FLOR 46455!).

Notes. Heinrich Wilhelm Schott (1857) described Anthurium chamissonis, making no reference to a preserved specimen or an illustration. In a later work, Schott (1860: 459) added the comment "Brasilia Chamisso. - v.s. specimen. spont. in Herb. G. Berol." The type, we presume, was destroyed in World War II, but it is represented by photocopy no. 11933 in the Type Photograph Collection of the Field Museum, Chicago (F) with a determination slip in Schott's handwriting. Since the holotype was probably destroyed and there is no original illustration, we designate a neotype matching the characteristics in the original description. The chosen neotype is consistent with the morphologic features presented by Schott in the protologue and with the interpretation of Reitz (1957) and Valadares and Sakuragui (2014), who recognized all the A. gaudichaudianum varieties described by Engler as synonyms of A. gaudichaudianum. This species has great morphological and ecological amplitude and the synonymizations proposed by these authors were based on study of a large amount of material.

5. Anthurium gaudichaudianum var. libonianum (Linden \& Regel) Engl., Fl. Bras. (Martius) 3(2): 85. 1878. Basionym: Anthurium libonianum Linden \& Regel, Gartenflora 16: 291, t. 558. 1867. TYPE: [Icon in] Regel, Gartenflora 16: t. 558. 1867 (lectotype, designated here, t. 558 in Regel [1867]).

Notes. Anthurium libonianum was published by Jean Jules Linden and Eduard von Regel in Gartenflora (1867) with no reference to a preserved specimen but with a black-and-white illustration of habit and inflorescence. We did not find any original material in the herbaria. We therefore select t. 558 as the lectotype.

6. Anthurium geitnerianum Regel, Gartenflora 16: 99, t. 540. 1867. TYPE: [Icon in] Regel, Gartenflora 16: t. 540.1867 (lectotype, designated here, t. 540 in Regel [1867]).

Notes. Anthurium geitnerianum was validly published by Eduard von Regel (Regel, 1867), but no locality was cited. In his original description, Regel mentions that plants were sent to him by Hermann Geitner (Garden Zwickau). We did not find any original herbarium material unambiguously associated with the protologue. Saint Petersburg Herbarium has one specimen of A. geitnerianum identified by Regel that would be a reasonable candidate to be the type, but comparative analysis of the protologue and associated illustration does not provide clear evidence that the specimen certainly belongs to the original material. We therefore select t. 540, which contains a black-and-white illustration of habit, lateral primary veins, inflorescence, and detail of the flower, as the lectotype.

7. Anthurium gladiifolium Schott, J. Bot. 1: 5. 1863. TYPE: [Icon in] Aroideae Maximilianae: t. 9.1879 (neotype, designated here, t. 9 in Schott [1879]).

Notes. Anthurium gladiifolium was described by Heinrich Wilhelm Schott (1863). The original material was part of the collection made by Franz Maly in January 1860, during Archduke Ferdinand Maximilian's expedition to Brazil, and was presumably destroyed during the Second World War (Riedl \& Riedl-Dorn, 1988). Subsequently, Schott (1879) illustrated A. gladiifolium, cultivated at the Imperial Gardens, Schönbrunn Palace, Austria, in the Aroideae Maximilianae. Because the species is illustrated in detail in a plate and Schott clearly mentions that all illustrated material proceeded from Archduke Ferdinand Maximilian's expedition, we chose the plate as the neotype.

8. Anthurium glaucescens Kunth, Enum. Pl. 3: 73. 1841. TYPE: Brazil. Rio de Janeiro: Monumento Natural dos Morros do Pão de Açúcar, R. T. Valadares \& L. S. B. Calazans 1488 (neotype, designated here, RB 733754!).

Notes. Anthurium glaucescens was described by Kunth with no references to any preserved specimen or figure. We did not find materials in the European herbaria, nor illustrations that could be unambiguously associated with the original description. We therefore designate a neotype, which best represents characteristics in the description presented in the protologue. This name is traditionally recognized as a synonym of A. coriaceum (Engler, 1878, 1898, 1905; Croat, 1991; BFG-The Brazil Flora Group, 2015), as we also assumed here, a species with great morphological and ecological amplitude captured in countless gatherings from the Brazilian Atlantic Forest. The selected neotype shows vegetative features (leaf blade shape and the ratio between leaf blade and petiole) consistent with Kunth's description, and the ratio between spathe and spadix length, a fundamental feature to identify some species of subsection Obscureviridia, is similar to that presented by Kunth. The neotype we selected definitely belongs to A. coriaceum, as shown by features including a short stem, coriaceous leaf blade, non-revolute spathe, and more than nine flowers per spiral. These last two features are the best for distinguishing A. coriaceum from other Obscureviridia species (see Coelho \& Valadares, 2019).

The names "Pothos glaucus Schott ex Kunth" and "Pothos reflexus Hoffm. ex Kunth" were given by Kunth (1841) as synonyms of Anthurium glaucescens and are therefore not validly published. 
9. Anthurium inconspicuum N. E. Br., Gard. Chron. 23: 787. 1885. TYPE: Brazil. Rio de Janeiro, A. F. M. Glaziou s.n. (holotype, K [K434167]!).

Notes. Nicholas Edward Brown (1885) published Anthurium inconspicuum based on a specimen from "Rio Janeiro" sent by Auguste François Marie Glaziou to Kew. Brown (1885: 787) observed that Glaziou labeled all his Brazilian specimens as coming from Rio Janeiro, and "it is quite certain that some of them come originally from other parts of Brazil." The specimen K434167 has Brown's handwritten determination indicating this material as "Type specimen!" with the citation of the name, leaving no doubt about the material he analyzed. Some specimens at K (K 1239520, K 1239521, K 1239523), P (P00748718, P00748719, P00748720, P02136692, P02136693), and US (US01918782) of A. inconspicuum collected by Glaziou have been treated as possible types or syntypes. However, these other specimens have varying collection numbers, not found on the confirmed original material at Kew, and cannot be unambiguously linked to the protologue. Therefore, the cited specimen at Kew must be considered to be the holotype.

The name "Anthurium opacum Engl." was cited by Engler (1898) as a synonym of Anthurium inconspicuum and also appears on a Glaziou specimen we located at $\mathrm{P}$, “Arac. Exsicc. et illustr. n. 144." However, it has never been validly published.

10. Anthurium lacerdae Reitz, Sellowia 8: 59, t. 16. 1957. TYPE: Brazil. Santa Catarina: Rio Canoas, Luíz Alves, Itajaí, epífito em pau caído na mata, $50 \mathrm{~mm}$, P. R. Reitz 5158 (holotype, HBR presumed lost). [Icon in] Reitz, Sellowia 8: t. 16. 1957 (lectotype, designated here, t. 16 in Reitz [1957]).

Notes. According to the curator at HBR (Ademir Reis, pers. comm.), the holotype is lost. The protologue for this species provides a figure in which it is possible to recognize characteristics that distinguish Anthurium lacerdae from similar species, such as the short peduncle, three times wider than the spathe, and the inclined infructescence during fruiting. Since no other original material is available to be used, we have selected the illustration as the lectotype.

11. Anthurium longipetiolatum Engl., Bot. Jahrb. Syst. 25: 400. 1898. TYPE: Brasilia australis, A. F. M. Glaziou 16510 (lectotype, designated here, K 434157!; isolectotype, P 1750118!, P 1750124!).

Notes. Anthurium longipetiolatum was validly published by Heinrich Gustav Adolf Engler (1898: 401), with citation of the following materials: "Engl., Arac. exsicc. et illustr. n. 137 ... Brasilia australis (Glaziou n. 16510)." We have selected the duplicate of Glaziou
16510 deposited at Kew as the lectotype because it bears Engler's handwritten determination.

12. Anthurium microphyllum (Hook.) G. Don, Hort. Brit. [Sweet] 3: 633. 1839. Basionym: Pothos microphyllus Hook., Bot. Mag. 56: t. 2953. 1829. Podospadix microphylla (Hook.) Raf., Fl. Tellur. 4: 124. 1838 [1836]. TYPE: [Icon in] Hooker, Bot. Mag. 56: t. 2953. 1829 (lectotype, designated here, t. 2953 in Hooker [1829]).

Notes. Pothos microphyllus was described by William Jackson Hooker (1829) from a cultivated plant at the Glasgow Botanic Garden sent by Mr. Taite. We did not find any herbarium material associated with $P$. microphyllus. Therefore, we select the illustration in the protologue as the lectotype.

13. Anthurium rubriflorum Engl., Bot. Jahrb. Syst. 25: 399. 1898. TYPE: [Brazil]. Brasilia, Glaziou 71 $(\mathrm{B} \dagger)$. Brazil. São Paulo, Peruíbe, Barra do Uma, estação Ecológica Juréia-Itatins, E. L. M. Catharino et al. 1500 (neotype, designated here, SP 248062!; isoneotype, UNOP 410!).

Notes. The type of Anthurium rubriflorum was Glaziou 71, cultivated at the Berlin Botanic Garden and later destroyed during the Second World War. Therefore, it is necessary to designate a neotype that matches the description presented in the protologue. Like A. glaucescens, this name is traditionally recognized as a synonym of $A$. coriaceum (Croat, 1991; Valadares \& Sakuragui, 2014; BFG-The Brazil Flora Group, 2015), and our choice of neotype followed the same principles used for that name. The vegetative features (e.g., leaf blade shape) and the ratio between spathe and spadix length seen in the chosen neotype are consistent with Engler's description in the protologue, and the specimen can be definitely identified as belonging to $A$. coriaceum by the features enumerated above under A. glaucescens.

14. Anthurium willdenowii Kunth var. pohlii Engl., Fl. Bras. (Martius) 3(2): 84. 1878. TYPE: Brazil. Caxoeira d'Inferno, J. E. Pohl s.n. (W†) (lectotype, designated here, M 0198716!; isolectotype, BR 562245!).

Notes. Anthurium willdenowii var. pohlii was published by Engler in Flora Brasiliensis (Engler, 1878) from a specimen collected by Pohl in "Caxoeira d'Inferno" and seen at the Vienna Herbarium. This specimen was later destroyed in World War II, but there are duplicates at M and BR, both morphologically complete and with Engler's handwritten determination. We therefore select the specimen at M as the lectotype.

\section{Nomen Nudum}

Anthurium glaucum Schott, Wiener Z. Kunst 828. 1829. 
When Schott (1829) published "Anthurium glaucum," the only provided information was "Graugrüner Blütenschweif Aus Brasilien Aroideae" ("gray-greenish Anthurium from Brazil"). This information cannot be accepted as a valid description or diagnosis and therefore this designation must be treated as not validly published.

Acknowledgments. We are grateful to Claudine Mynssen for her suggestions about an early version of the manuscript, Wendy Applequist and three anonymous reviewers for their very rich contributions, Ademir Reis for information on Anthurium lacerdae, and Erica Barroso, Vladimir Dorofeyev, Ricardo S. Couto, and Mia Ehn for providing images of types from the British Museum (BM), Saint Petersburg (LE), and Stockholm (S) herbaria, respectively. This study was financed in part by the Coordenação de Aperfeiçoamento de Pessoal de Nível Superior (CAPES) - Finance Code 001 (Ph.D. scholarship to R. T. V.) and by the Conselho Nacional de Desenvolvimento Científico e Tecnológico (CNPq) (Ph.D. scholarship to L. S. B. C. and research fellowship to C. M. S.).

Literature Cited

BFG-The Brazil Flora Group. 2015. Growing knowledge: An overview of seed plant diversity in Brazil. Rodriguésia 66: 1085-1113.

Brown, N. E. 1885. Anthurium inconspicuum. New garden plants. Gard. Chron. 23: 787.

Coelho, M. A. N. \& S. J. Mayo. 2007. Typifications of names of Brazilian taxa of Anthurium sect. Urospadix (Araceae). Taxon 56: 211-225.

Coelho, M. A. N. \& R. T. Valadares. 2019. Three New Species of Anthurium (Araceae) from the Atlantic Forest of Rio de Janeiro, Minas Gerais, and Espírito Santo, Brazil. Novon 27(1): 22-32.

Coelho, M. A. N., J. L. Waechter \& S. J. Mayo. 2009. Taxonomic revision of species of the Anthurium (Araceae) section Urospadix subsection Flavescentiviridia. Rodriguésia 60: 799-864.

Croat, T. B. 1976. Studies in Araceae I: Section Leptanthurium Schott-The Anthurium gracile-friedrichsthalii complex of Central and South America. Selbyana 1: 357-364.

Croat, T. B. 1991. A revision of Anthurium section Pachyneurium (Araceae). Ann. Missouri Bot. Gard. 78: 539-855.

Engler, A. 1878. Araceae. Pp. 56-88 in C. F. P. Martius (editor), Flora Brasiliensis. F. Fleischer, Munich, Leipzig.

Engler, A. 1898. Revision of the genus Anthurium Schott. Bot. Jahrb. Syst. 25: 352-476.

Engler, A. 1905. Araceae-Pothoideae. Pp. 1-330 in A. Engler (editor), Das Pflanzenreich IV. 23B(Heft 21). W. Engelman, Leipzig.
Graham, R. 1826. Dr Graham's List of Rare Plants. Edinburgh New Philos. J. 1: 172-173.

Hooker, W. J. 1829. Pothos mycrophyllus. Bot. Mag. 56: t. 2953.

Kunth, C. S. 1841. Enumeratio Plantarum, 3: Enumeratio Aroidearum. Sumtibus J. G. Cottae, Stuttgart.

Lauener, L. A. \& H. Paul. 1985. The type specimens of Robert Graham. Notes Roy. Bot. Gard. Edinburgh 42: $567-593$.

Mayo, S. J. 1982. Anthurium acaule (Jacq.) Schott (Araceae) and West Indian 'bird's nest' Anthuriums. Kew Bull. 36: 691-719.

Regel, E. A. 1867. Originalabhandlungen: Anthurium geitnerianum. Gartenflora 16: 99.

Regel, E. A. 1872. Originalabhandlungen: Anthurium binoti. Gartenflora 21: 131-132.

Reitz, R. 1957. Aroid from Santa Catarina. Sellowia 8: 20-70.

Riedl, H. \& C. Riedl-Dorn. 1988. Heinrich Wilhelm Schott's botanical collections at the Vienna Natural History Museum (W). Taxon 37: 846-854.

Salisbury, R. A. 1796. Prodromus Stirpium in Horto ad Chapel Allerton Vigentium. London.

Schott, H. W. 1829. For lovers of botany. Wiener Z. Kunst 3: 828.

Schott, H. W. 1857. Aroideae-sketchy. Oesterr. Bot. Z. 34: 269-270.

Schott, H. W. 1860. Prodromus Systematis Aroidearum. Typis Congregation Mechitharisticae, Vienna.

Schott, H. W. 1863. Anthurium gladiifolium, a new Brazilian aroidea. J. Bot. 1: 5-6.

Schott, H. W. 1879. Aroideae Maximilianae. Druck \& Verlag von Carl Gerold's Sohn, Vienna.

Stafleu, F. A. \& R. S. Cowan. 1976-1988. Taxonomic Literature: A Selective Guide to Botanical Publications and Collections with Dates, Commentaries and Types, Vols. 1-7. Bohn, Scheltema \& Holkema, Utrecht.

Sweet, R. \& G. Don. 1839. Sweet's Hortus Britannicus; Or, a Catalogue of Plants Cultivated in the Gardens of Great Britain Arranged in Natural Orders, Etc. J. Ridgway, London.

Thiers, B. 2019 [continuously updated]. Index Herbariorum: A global directory of public herbaria and associated staff. $<$ http://sweetgum.nybg.org/science/ih/>, accessed 4 October 2017.

Turland, N. J. 2013. The Code Decoded: A User's Guide to the International Code of Nomenclature for Algae, Fungi, and Plants, Vol. 155. Koeltz Scientific Books, Königstein.

Turland N. J., J. H. Wiersema, F. R. Barrie, W. Greuter, D. L. Hawksworth, P. S. Herendeen, S. Knapp, et al. (editors). 2018. International Code of Nomenclature for algae, fungi, and plants (Shenzhen Code). Regnum Veg. 159.

Valadares, R. T. \& C. M. Sakuragui. 2014. A new species of Anthurium (Araceae) sect. Urospadix subsect. Obscureviridia from Espírito Santo, Eastern Brazil. Syst. Bot. 39: 31-35. 